\title{
PENYULUHAN PROGRAM PERILAKU HIDUP BERSIH DAN SEHAT (PHBS) MELALUI KEGIATAN CUCI TANGAN PAKAI SABUN PADA PENDIDIKAN ANAK USIA DINI
}

\author{
Yesi Novitasari ${ }^{1}$, Heleni Filtri ${ }^{2}$, Suharni ${ }^{3}$ \\ ${ }^{1)}$ Dosen Prodi Pendidikan Guru Pendidikan Anak Usia Dini, FKIP, Unilak \\ Email: yesinovitasari@unilak.ac.id
}

\begin{abstract}
ABSTRAK
Kesehatan merupakan hal yang terpenting dalam kehidupan manusia dan kesehatan menjadi kata kunci kebahagian anak usia dini. Hal tersebut dapat dicapai dengan perilaku hidup bersih dan sehat. Hidup sehat dapat dicapai dengan cara perilaku menjaga kebersihan diri, dan perilaku menjaga kebersihan diri dapat dilakukan dengan hal yang paling mudah salah satunya dengan cara mencuci tangan menggunakan sabun. Dengan pembiasaan perilaku hidup bersih dan sehat tentu saja dapat mengoptimalkan pertumbuhan dan perkembangan anak diperiode golden age. Program Perilaku Hidup Bersih dan Sehat Melalui Kegiatan Cuci Tangan Pakai Sabun belum dijalankan di PAUD Mutiara Cendekia, sehingga anak belum terbisa mencuci tangan setelah selesai melakukan kegiatan. Kondisi ini menyebabkan anak disekolah tidak dalam keadaan benar-benar bersih, sehingga beberapa anak banyak terserang kuman dan virus. Adapun solusi yang ditawarkan yaitu Penyuluhan Program Perilaku Hidup Bersih dan Sehat (PHBS) Melalui Kegiatan Cuci Tangan Pakai Sabun pada Pendidikan Anak Usia Dini Mutiara Cendekia. Melalui kegiatan ini diharapkan anak-anak, orang tua dan guru dapat menyadari pentingnya kebersihan dan mampu membiasakan diri untuk berperilaku hidup bersih dan sehat sejak usia dini, salah satunya dengan terbiasa mencuci tangan menggunakan sabun dengan cara yang baik dan benar setelah selesai melakukan kegiatan di dalam maupun di luar ruangan. Berdasarkan hasil analisis data yang diperoleh dapat disimpulkan bahwa perilaku hidup bersih dan sehat melalui cuci tangan setelah dilaksanakan penyuluhan mengalami peningkatan signifikan. Hal ini tergambar dari adanya peningkatan persentase angket orangtua dari 57.18 dengan kategori cukup baik menjadi 76.56 yang berada pada kategori baik.
\end{abstract}

Kata Kunci : PHBS, cuci tangan pakai sabun, anak usia dini

\begin{abstract}
The healthy is the most important thing in human life and health become the keyword of happiness for young children. This can be achieved with clean and healthy living behavior. Healthy living can be achieved by maintaining personal hygiene, and personal hygiene can be done with the easiest one of them by washing hands with soap. The habits of clean and healthy living behavior of course can optimize the growth and development of children in the golden age period. Clean and Healthy Life Behavior Program through Hand Washing with Soap Activity has not yet been run in PAUD Mutiara Cendekia, so the children has not been able to wash hands after completing the activity. This condition causes children in school not in a state of utterly clean, so some children are attacked by germs and viruses. The solution offered is Counseling of Clean and Healthy Life Behavior Program through Handwashing Activity with Soap on Early Childhood Education. This activity it is expected that children, parents and teachers can realize the importance of hygiene and able to get used to live clean and healthy life from an early age, one of them by getting used to wash hands with soap in a good way and right after finished doing activities in or outdoors. Based on the results of data analysis obtained can be concluded that the Clean and Healthy Life Behavior Program through Hand Washing with Soap Activity after the extension has increased significantly. This is reflected in the increased percentage of parent inquiries from 57.18 with good enough category to be 76.56 which is in good category.
\end{abstract}

Key words: CHLB, Hand Washing with Soap, Early Childhood 


\section{PENDAHULUAN}

Peningkatan kualitas sumber daya manusia harus dilakukan sejak dini secara sistematis dan berkesinambungan. Tumbuh berkembangnya anak usia dini yang optimal tergantung tiga pilar layanan, yaitu asupan gizi, layanan kesehatan dan stimulasi psikososial. Layanan kesehatan sangat berpengaruh pada lingkungan sekitar, baik di rumah maupun di sekolah, sehingga orang tua, pengasuh, dan pendidik harus bekerja sama untuk memberikan lingkungan dan stimulasi berupa pembiasaan perilaku hidup bersih dan sehat yang konsisten dan berkesinambungan kepada anak usia dini.

Perilaku hidup bersih dan sehat adalah semua perilaku kesehatan yang dilakukan atas kesadaran sehingga anggota keluarga atau keluarga dapat menolong dirinya sendiri di bidang kesehatan dan berperan aktif dalam kegiatan-kegiatan kesehatan di masyarakat. Perilaku hidup bersih dan sehat (PHBS) perlu dibiasakan sebagai kegiatan sehari-hari dalam kehidupan, baik itu dilakukan di rumah maupun di sekolah/lembaga PAUD, dimulai dari dalam keluarga dan pemodelan guru PAUD setiap hari di sekolah sehingga PHBS akan membentuk perilaku yang sehat bagi anak.

Manfaat mengembangkan perilaku hidup bersih dan sehat sejak dini adalah anak akan memiliki pola hidup sehat di kemudian hari. Artinya anak usia dini yang terbiasa dengan perilaku hidup bersih dan sehat tidak mudah hilang pada tahapan perkembangan selanjutnya. Selain itu anak usia dini telah memiliki pola hidup sehat, maka mereka akan terbebas dari serangan berbagai macam penyakit yang sering terjadi pada anak usia dini, seperti batuk/pilek, flek atau TBC,diare, demam, campak, infeksi telinga, dan penyakit kulit. Dalam kondisi bersih dan sehat berbagai kemampuan yang dimiliki anak usia dini akan tergali dan dapat dikembangkan dengan baik, sehingga anak usia dini dapat tumbuh dan berkembang optimal.

\section{TINJAUAN PUSTAKA}

Menurut Syahreni (2011:3) perilaku adalah kegiatan yang dilakukan oleh individu (seseorang), baik yang dapat diamati (dilihat) secara langsung maupun tidak langsung.Sehat adalahsuatu kondisi atau keadaan yang baik, mencakup fisik, mental dan sosial, jadi bukan hanya terbebas dari penyakit saja. Sehingga perilaku sehat adalah tindakan sesorang atau kegiatan yang dilakukan oleh seseorang, baik langsung maupun tidak langsung, untuk mempertahankan dan meningkatkankesehatannya serta mencegah resiko penyakit.

Kesehatan menurut Undang Undang Republik Indonesia tentang Kesehatan (No. 36 Tahun 2009) adalah keadaan sehat, baik secara fisik, mental, spritual maupun sosial yang memungkinkan setiap orang untuk hidup produktif secara sosial dan ekonomis. Selaras dengan Undang-Undang definisi sehat yang dikemukakan oleh World Health Organization (WHO) menyatakan sehat adalah keadaan sejahtera jasmani, jiwa dan sosial yang sempurna dan bukan hanya keadaan tanpa penyakit. Jadi, sehat secara menyeluruh melibatkan faktor fisik, mental dan sosial.

Berdasarkan dari pengertian di atas disimpulkan bahwa perilaku sehat adalah suatu sikap seseorang terhadap sistem pelayanan kesehatan, sakit dan penyakit, makanan dan minuman serta lingkungan, sehingga seseorang harus mendapatkan zat gizi yang sesuai dengan kebutuhannya, melakukan olah raga secara rutin, memiliki waktu tidur atau istirahat yang cukup, menjaga kebersihan diri dan lingkungan, supaya terhindar dari berbagai macam penyakit. Salah satu program perilaku hidup bersih dan sehat yang tepat dan bermanfaat 
yang dapat dilakukan untuk anak usia dini yaitu mencuci tangan dengan sabun setelah selesai melakukan kegiatan didalam ruangan, maupun setelah bermain di luar ruangan.

Priyono menjelaskan mencuci tangan adalah kegiatan membersihkan bagian telapak, punggung tangan, jari dan kuku jari, tujuannya agar bersih dari kotoran dan membunuh kuman penyebab penyakit dapat yang merugikan kesehatan (2015:1). Selain itu Kemenkes Republik Indonesia (2014:3) menjelaskan bahwa mencuci tangan dengan sabun adalah salah satu tindakan sanitasi dengan membersihkan tangan dan jari jemari menggunakan air dan sabun oleh manusia untuk menjadi bersih dan memutuskan mata rantai kuman.

Namun, kebiasaan mencuci tangan dengan sabun yang baik itu tidak disadari oleh sebagian anak-anak. Anak-anak memandang sabun hanya bermanfaat untuk menghilangkan kotor dan bau. Untuk melakukan program mencuci tangan cuci tangan dengan sabun, ketersedian air dan sabun untuk mencuci tangan sebenarnya bukan masalah tapi menjadi hambatan adalah faktor kebiasaan anak-anak. Untuk itu diperlukan peran pengasuh/pendidik anak usia dini untuk memberikan program yang bermanfaat kepada anak, yaitu membiasakan mencuci tangan dengan sabun setelah selesai melakukan kegiatan di sekolah.

Mencuci tangan dengan air saja ternyata tidak cukup untuk melindungi seseorang dari kuman penyakit yang menempel di tangan. Penggunaan sabun pada saat mencuci tangan menjadi penting karena sabun sangat membantu menghilangkan kuman yang tidak tampak seperti minyak/lemak/kotoran dipermukaan kulit serta meninggalkan bau wangi sehingga dapat memperoleh kebersihan yang berpadu dengan bau wangi dan perasaan segar setelah mencuci tangan dengan sabun, hal ini tidak akan didapat jika hanya menggunakan air saja. Selain itu mencuci tangan dengan sabun harus dilakukan dengan gerakan yang baik dan benar agar mendapatkan kebersihan yang maksimal.

Menurut World Health Organization (WHO, 2008) terdapat 7 langkah cara mencuci tangan menggunakan air dan sabun dengan baik dan benar sebagai berikut:

a. Basuh tangan dengan air bersih yang mengalir, ratakan sabun dengan kedua telapak tangan

b. Gosok punggung tangan dan sela - sela jari tangan kiri dan tangan

kanan, begitu pula sebaliknya.

c. Gosok kedua telapak dan sela - sela jari tangan

d. Jari - jari sisi dalam kedua tangan saling mengunci.

e. Gosok ibu jari kiri berputar dalam genggaman tangan kanan dan lakukan sebaliknya.

f. Gosokkan dengan memutar ujung jari-jari tangan kanan di telapak tangan kiri dan sebaliknya

g. Bilas kedua tangan dengan air yang mengalir dan keingkan

Mitra dalam pengabdian ini adalah PAUD Mutiara Cendekia. Paud Mutiara Cendekia terdiri dari 4 orang pendidik dan 30 anak beserta orang tuanya. Berdasarkan wawancara dengan beberapa orang guru, banyak anak yang belum terbiasa dengan PHBS yang salah satunya yaitu mencuci tangan menggunakan sabun. Dampak negative dengan tidak membiasakan mencuci tangan dengan sabun diantaranya anak terserang kuman dan virus sehingga ada beberapa anak yang mudah sakit bahkan beberapa diantaranya sering izin tidak masuk sekolah dikarenakan demam. Dampak lainnya yaitu anak tidak bertumbuh 
dan berkembang dengan optimal dimasa keemasannya, sehingga mempengaruhi hidupnya dimasa-masa mendatang.

Adapun solusi yang ditawarkan oleh tim pengusul program pengabdian adalah Penyuluhan Program Perilaku Hidup Bersih dan Sehat (PHBS) Melalui Kegiatan Cuci Tangan Pakai Sabun pada Pendidikan Anak Usia Dini Mutiara Cendekia. Setelah adanya pengabdian ini diharapakan anak-anak, orang tua dan guru dapat menyadari pentingnya kebersihan dan mampu membiasakan diri untuk berperilaku hidup bersih dan sehat sejak usia dini, salah satunya dengan terbiasa mencuci tangan menggunakan sabun setelah selesai melakukan kegiatan di dalam dan di luar ruangan.

\section{METODE PELAKSANAAN}

\section{Persoalan dan Solusi yang Ditawarkan.}

Dalam kegiatan pengabdian ini, yang menjadi persoalan adalah permasalahan yang ditemukan yakni banyaknya anak yang belum terbiasa dengan PHBS salah satunya yaitu mencuci tangan menggunakan sabun. Adapun solusi yang ditawarkan oleh tim pengusul program IbM adalah Penyuluhan Program Perilaku Hidup Bersih dan Sehat (PHBS) Melalui Kegiatan Cuci Tangan Pakai Sabun pada Pendidikan Anak Usia Dini Mutiara Cendekia. Setelah adanya IbM ini diharapakan anak-anak, orang tua dan guru dapat menyadari pentingnya kebersihan dan mampu membiasakan diri untuk berperilaku hidup bersih dan sehat sejak usia dini, salah satunya dengan terbiasa mencuci tangan menggunakan sabun setelah selesai melakukan kegiatan di dalam dan di luar ruangan. Penggalian informasi awal melalui wawancara dan survey lapangan dan penandatanganan kerjasama kegiatan IbM.

\section{Prosedur Kerja}

Prosedur yang dilakukan dalam kegiatan ini terdiri dari beberapa rangkaian kegiatan, mulai dari melakukakan kegiatan analisis situasi berupa observasi lapangan dan interview sampai kepada pembuatan proposal dan laporan kegiatan pengabdian kepada masyarakat. Kemudian untuk pelaksanaan kegiatan sosialisasi menggunakan metode ceramah, diskusi atau tanya jawab. Prosedur yang dilakukan dalam kegiatan IbM ini terbagi 2 sesi yang dilakukan selama 1 hari

\section{Sesi 1}

Pada sesi ini dilakukan persiapan materi Penyuluhan Program Perilaku Hidup Bersih dan Sehat (PHBS) pada Pendidikan Anak Usia Dini. Dalam penyuluhan ini digunakan media audio-visual (ICT). Metode yang digunakan adalah metode ceramah dan diskusi untuk menjelaskan materi. Materi penyuluhan yang disampaikan adalah sebagai berikut:

a. Penjelasan tentang Program Perilaku Hidup Bersih dan Sehat (PHBS) pada Pendidikan Anak Usia Dini oleh Heleni Filtri, M.Psi

b. Penjelasan tentang Kegiatan Cuci Tangan Pakai Sabun pada Pendidikan Anak Usia Dini oleh Yesi Novitasari, M.Pd.

c. Praktik 7 Langkah Mencuci Tangan Menggunakan Sabun oleh Suharni, M.Pd.

\section{Sesi 2}

Pada sesi kedua ini digunakan metode diskusi dan tanya jawab. Hal ini bertujuan untuk mengetahui sejauh mana pemahaman mahasiswa tentang materi yang disampaikan. 
3. Lokasi dan Peserta Kegiatan

Kegiatan pengabdian masyarakat ini dilakukan di PAUD Mutiara Cendekia.

\section{HASIL DAN PEMBAHASAN}

Penyuluhan Program Perilaku Hidup Bersih dan Sehat (PHBS) melalui kegiatan cuci tangan pakai sabun pada Pendidikan Anak Usia Dini telah dilakukan pada tanggal 5 April 2018. Penyuluhan ini berjalan lancar dan peserta mengikuti dengan baik. Berdasarkan angket yang disebarkan kepada peserta, hasil dari respon angket menggambarkan bahwa penyuluhan sangat bermanfaat bagi orangtua. Hal itu tergambar dari peningkatan persentase pengetahuan orangtua tentang cuci tangan pakai sabun pada Pendidikan Anak Usia Dini sebelum dan sesudah diberikan penyuluhan.

Berdasarkan hasil pengolahan data, maka gambaran tentang pengetahuan orangtua terhadap Program Perilaku Hidup Bersih dan Sehat (PHBS) melalui kegiatan cuci tangan pakai sabun pada Pendidikan Anak Usia Dini, secara umum berada pada kategori cukup baik dengan rata-rata 57.18. Sedangkan setelah dilaksanakan penyuluhan, secara umum berada pada kategori baik dengan rata-rata 76.56. Berdasarkan data tersebut perilaku hidup bersih dan sehat melalui cuci tangan setelah dilaksanakan penyuluhan mengalami peningkatan signifikan dengan kenaikan persentase sebesar 19.38.

\section{KESIMPULAN DAN SARAN Kesimpulan}

Berdasarkan analisis data yang dilakukan maka dapat ditarik kesimpulan bahwa :

1. Penyuluhan perilaku hidup bersih dan sehat melalui cuci tangan dengan sabun pada pendidikan anak usia dini bermanfaat bagi orangtua, guru dan anak. Dengan adanya kegiatan penyuluhan ini, orangtua dan guru semakin menyadari tentang pentingnya pencegahan penyakit dengan mencuci tangan dengan sabun.

2. Terdapat peningkatan pengetahuan orangtua, guru dan anak tentang perilaku hidup bersih dan sehat melalui mencuci tangan dengan sabun secara baik dan benar setelah diberikan penyuluhan. Hal ini tergambar dari peningkatan persentase angket orangtua. Peningkatan ini menunjukkan bahwa penyuluhan efektif dalam meningkatkan pengetahuan orangtua dalam berperilaku hidup bersih dan sehat.

\section{Saran}

Berdasarkan hasil yang telah dipaparkan di atas, maka dapat dikemukakan saran sebagai berikut :

1. Hendaknya penyuluhan perilaku hidup bersih dan sehat melalui cuci tangan dengan sabun pada pendidikan anak usia dini ini tidak hanya diadakan di PAUD Mutiara Cendekia saja tetapi juga diadakan di TK yang lain karena sangat bermanfaat bagi orangtua, guru dan anak.

2. Sebaiknya penyuluhan ini dilakukan dalam waktu yang lebih lama sehingga orangtua, guru dan anak bisa mendapatkan pengetahuan serta dapat mendemonstrasikan bagaimana cara mencuci tangan pakai sabun dengan cara yang baik dan benar. 


\section{DAFTAR PUSTAKA}

[5]. Kementerian Kesehatan RI. 2005. Undang - Undang Nomor 36 Tahun 2009 Tentang Kesehatan. Jakarta: Kemenkes

[6]. Pusat Data dan Informasi Kementerian Kesehatan RI. 2014. Perilaku Mencuci Tangan Pakai Sabun di Indonesia. Jakarta: Kemenkes.

[7]. Priyono, Ega. 2015. Meningkatkan Kebiasaan Mencuci Tangan Pada Siswa Sekolah Dasar Melalui Penerapan Alat Bantu Media Audio Visual Dalam Kegiatan Pembelajaran Pendidikan Kesehatan. Bandung: Universitas Pendidikan Indonesia. Diakses melalui http:// repository.upi.edu pada 14 Februari 2018

[8]. Riduwan. 2010. Skala Pengeukuran Variabel-variabel Penelitian. Bandung: Alfabeta.

[9]. Syahreni, E. 2011.Mengembangkan Perilaku Sehat Pada Anak Usia 2-4 Tahun. Jakarta: Direktorat Pembinaan Pendidikan Anak Usia Dini Direktorat Jenderal Pendidikan Anak Usia Dini Nonformal danInformal Kementerian Pendidikan Nasional.

[10]. World Health Organization, 2008. The World Health Report 2008. Switzerland: WHO Press 